\title{
THE IMAGE OF IAIN PADANGSIDIMPUAN AMONG HIGH ACHIEVEMENT STUDENTS (EDUCATIONAL SERVICES MARKETING PERSPECTIVE)
}

\author{
Muhammad Isa \& BUDI GAUTAMA SIREGAR \\ IAIN Padangsidimpuan \\ Email: misastmm@gmail.com \& budigautamasrg20@gmail.com \\ DOI: $h t t p: / / d x . d o i . o r g / 10.24952 /$ tazkir.v5i2.2314
}

\begin{abstract}
The presence of students in a tertiary institution is an absolute requirement that must be met. IAIN Padangsidimpuan applies three different types of selection of new student candidates. These include the National Academic Achievement Selection (Seleksi Prestasi Akademik Nasional/SPAN PTKIN), the State Islamic College Entrance Examination (Ujian Masuk Perguruan Tinggi Agama Islam Negeri/UM - PTKIN), and Independent Exams. SPAN - PTKIN is intended to recruit prospective new students from high achieving students. However, many prospective students who passed the SPAN-PTKIN pathway did not re-register again. This condition occurs almost every year. SPAN - PTKIN is intended to recruit prospective new students from high achieving students. However, many prospective students who passed the SPAN-PTKIN pathway did not re-register. This condition occurs almost every year. This has led to the presumption that there is a tendency for prospective new students from high achieving students through the SPAN-PTKIN pathway to have low interest in continuing education at the Padangsidimpuan IAIN. So it needs to be investigated how the actual image of IAIN Padangsidimpuan among high achieving students and other related aspects. This is important as input for improving the selection system for prospective new students or making decisions in the planning of promotion strategies for Padangsidimpuan IAIN in the future. This research is a descriptive quantitative research. The population of this study was all high achieving students at the State High School / Islamic High School level in Padangsidimpuan City. The main instrument was a questionnaire distributed to 220 respondents, which were selected by purposive sampling technique. Data analysis was performed by t-test and ANOVA. Data processing is done by SPSS software. From the results of data processing, it is known that the overall Iangs Padangsidimpuan imagery among Padangsidimpuan City achievers is included in the "good" category, with a value of 3,2353 from the maximum scale of 5. The t test results are known that, the Islamic High School students' point of view regarding the image of IAIN Padangsidimpuan is better than state school students. Therefore, it is necessary to do more frequent promotion to the state schools. From the ANOVA test results it is known that there is actually no difference in the image of the IAIN Padangsidimpuan between groups of respondents from different family classes. This indicates that IAIN Padangsidimpuan does not need to differentiate promotion methods for students from economically well-off families, middle class, or poor families.
\end{abstract}

Key Words: Image, achievement students, marketing, and perspectives. 


\begin{abstract}
Abstrak
Keberadaan mahasiswa dalam sebuah perguruan tinggi merupakan persyaratan mutlak yang harus dipenuhi. IAIN Padangsidimpuan menerapkan tiga jenis seleksi calon mahasiswa baru yang berbeda. ketiganya yaitu Seleksi Prestasi Akademik Nasional (SPAN - PTKIN), Ujian Masuk Perguruan Tinggi Keagamaan Islam Negeri (UM PTKIN), dan Ujian Mandiri. SPAN - PTKIN ditujukan untuk menjaring calon mahasiswa baru dari kalangan siswa berprestasi. Namun, banyak calon mahasiswa yang lulus dari jalur SPAN-PTKIN yang tidak melakukan daftar ulang kembali. Kondisi ini terjadi hampir setiap tahun. Hal ini menimbulkan praduga bahwa ada kecenderungan calon mahasiswa baru yang berasal dari kalangan siswa berprestasi melalui jalur SPAN-PTKIN memiliki minat yang rendah untuk melanjutkan pendidikan di IAIN Padangsidimpuan. Perlu diteliti bagaimana sebenarnya citra IAIN Padangsidimpuan di kalangan siswa berprestasi dan aspek terkait lainnya perlu diteliti dan diketahui. Hal ini penting sebagai masukan untuk perbaikan sistem seleksi calon mahasiswa baru maupun pengambilan keputusan dalam perencanaan strategi promosi IAIN Padangsidimpuan pada masa yang akan datang. Penelitian ini merupakan penelitian kuantitatif deskriptif. Populasi penelitian ini adalah seluruh siswa berprestasi pada jenjang SMA/MA sederajat seKota Padangsidimpuan. Instrumen utamanya adalah kuesioner yang dibagikan kepada 220 orang responden, yang dipilh dengan teknik purposive sampling. Analisis data dilakukan dengan uji $t$ dan ANOVA. Pengolahan data dilakukan dengan bantuan software SPSS. Dari pengolahan data yang dilakukan diketahui bahwa citra IAIN Padangsidimpuan secara keseluruhan di kalangan siswa berprestasi seKota Padangsidimpuan termasuk dalam kategori "baik" dengan nilai 3,2353 dari maksimum skala 5. Dari uji $\mathbf{t}$ yang dilakukan diketahui bahwa siswa madrasah memandang citra IAIN Padangsidimpuan lebih baik daripada siswa sekolah umum. Oleh karena itu perlu dilakukan promosi yang lebih sering ke sekolah-sekolah umum. Dari hasil uji ANOVA diketahui bahwa sebenarnya tidak ada perbedaan citra IAIN Padangsidimpuan antara kelompok responden dari kelas keluarga yang berbeda. Hal ini mengindikasikan bahwa IAIN Padangsidimpuan tidak perlu membedakan metode promosi untuk siswa dari golongan keluarga mampu, menengah, atau keluarga kurang mampu.
\end{abstract}

Kata Kunci: citra, siswa berprestasi, pemasaran, dan perspektif.

\title{
INTRODUCTION
}

The first principle of Pancasila, namely "Godhead of the Almighty", has inspired the life of the Indonesian people. Spiritual values cannot be separated from the life of the Indonesian people, even though the Republic of Indonesia is not a religious state. In the government structure of the Republic of Indonesia it is known that there is a Ministry of Religion which is in charge of taking care and 
handling religious affairs in social life including the fields of religious and religious education.

Padangsidimpuan IAIN is one of the many tertiary institutions under the Ministry of Religion of the Republic of Indonesia in the City of Padangsidimpuan, North Sumatra. The community and managers of IAIN Padangsidimpuan continue to strive and hope that this tertiary institution can develop and progress rapidly. These expectations include: the transformation of IAIN Padangsidimpuan into UIN, Accreditation of all Study Programs worth A, representative buildings and so on. One component that supports the realization of the above expectations is the number of students. The more students of IAIN Padangsidimpuan, the faster and more realistic these expectations will be achieved.

In order to obtain qualified new students, and with a large number in terms of quantity, the IAIN Padangsidimpuan implemented three types of new student admissions selection, namely the National Academic Achievement Selection (Seleksi Prestasi Akademik Nasional/SPAN - PTKIN), the State Islamic College Entrance Examination (Ujian Masuk Perguruan Tinggi Agama Islam Negeri/UM - PTKIN), and Independent Exams. SPAN - PTKIN is intended to recruit prospective new students from high achieving students.

Based on information obtained by researchers from the Academic and Student Affairs Section of IAIN Padangsidimpuan, it turns out that many prospective students who graduated from the SPAN-PTKIN pathway did not reregister. This condition occurs almost every year, for example at the admission of new students in 2018, the number of prospective students who were declared to have passed through the SPAN - PTKIN pathway was 1725 people but only 779 people re-registered ( $45.15 \%$ from the original). ${ }^{1}$

This raises the preconceived notion that there is a tendency for prospective new students from high achieving students through the SPANPTKIN selection to have low interest in continuing their education at IAIN Padangsidimpuan. This condition must not be allowed to occur for a long time

\footnotetext{
${ }^{1}$ Recapitulation of SPMB IAIN Padangsidimpuan 2018
} 
and must be treated immediately. If these conditions continue to occur, it will harm the IAIN Padangsidimpuan in the long run. This phenomenon is quite interesting and needs further analysis. How the image of the IAIN Padangsidimpuan among outstanding students and other related aspects needs to be examined and known. This is important as an input for improving the selection system for prospective new students as well as making decisions in planning the promotion strategy of IAIN Padangsidimpuan in the future.

The problems raised above will be reviewed in this paper and titled "Image of IAIN Padangsidimpuan Among Achievement Students (Perspective of Educational Services Marketing Management)." The purpose of this study is to find out:1) The image of IAIN Padangsidimpuan among high achieving students, 2) The difference in the image of IAIN Padangsidimpuan from among high achieving students in Islamic High School compared to state schools, 3) The difference in the image of IAIN Padangsidimpuan among high achieving students from economically poor families, middle class, or well-off families.

\section{METHOD}

This research was conducted on high achieving students in all State Senior High School or equivalent Islamic High School in the City of Padangsidimpuan with the reason they were considered to know better and understand IAIN Padangsidimpuan better. The study was conducted from March 2019 to August 2019.

This type of research is quantitative descriptive. Descriptive method is used if the purpose of the study is to describe something. ${ }^{2}$

The population of this research is all high achieving students in State Senior High School or equivalent Islamic High School in Padangsidimpuan city. Researchers determine the sample by purposive sampling. Researchers use this method with certain criteria that need to be considered. ${ }^{3}$ Sample criteria are that

2 Istijanto, Aplikasi Praktis Riset Pemasaran:Cara Praktis Meneliti Konsumen dan Pesaing, Jakarta: PT. Gramedia Pustaka Utama, 2009. p. 33

${ }^{3}$ Riduwan, Belajar Mudah Penelitian:Untuk Guru-Karyawan dan Peneliti Pemula (Bandung: Alfabeta, 2010), page. 63. 
they can represent public/private schools; schools with good/moderate/bad reputation; state/vocational/ Islamic schools; active school status; and allowed to do research. Based on the above criteria, the researcher determined 22 schools/Islamic schools from 41 schools/Islamic schools in Padangsidimpuan City as the research location.

Researchers determined the sample of respondents in this study were the 10 best performing students who had been appointed/determined by the school/Islamic schools management as the research location. So that the total sample of respondents is 22 locations $x 10$ people/location, which is 220 people.

The main instrument of this study is the questionnaire. To complete and clarify the data the researcher also conducted interviews with related parties.

Research hypotheses are:

1. There is a difference in the image of IAIN Padangsidimpuan among high achieving students from Islamic and state schools

2. There is a difference in the image of the IAIN Padangsidimpuan among high achieving students from economically well-off families, middle class, or poor families.

Before the questionnaire was used, the validity and reliability tests were previously conducted. The collected data were analyzed by normality test, average calculation, $\mathrm{t}$ test, and ANOVA test with SPSS software.

\section{RESULT AND DISCUSSION}

\section{Result}

Data obtained from questionnaires filled out by respondents were then processed with SPSS software. SPSS output obtained is as follows:

Table 1. The average value of total respondents' answers

Descriptive Statistics

\begin{tabular}{|l|r|r|r|r|r|}
\hline & $\mathrm{N}$ & Minimum & Maximum & Mean & $\begin{array}{c}\text { Std. } \\
\text { Deviation }\end{array}$ \\
\hline Image & 17 & 2.52 & 3.79 & 3.2353 & .29566 \\
\hline
\end{tabular}


Descriptive Statistics

\begin{tabular}{|l|r|r|r|r|r|}
\hline & $\mathrm{N}$ & Minimum & Maximum & Mean & $\begin{array}{c}\text { Std. } \\
\text { Deviation }\end{array}$ \\
\hline Image & 17 & 2.52 & 3.79 & 3.2353 & .29566 \\
Valid N \\
(listwise)
\end{tabular}

From the data processing, it is known that the overall image of the Padangsidimpuan IAIN among Padangsidimpuan City achievers is included in the "good" category with a value of 3,2353 from a maximum scale of 5. Although it is categorized as good, it does not mean that the Padangsidimpuan IAIN does not need to make improvements. The image of the IAIN Padangsidimpuan can still be improved to obtain better grades. This means that the manager of the Padangsidimpuan IAIN must still make the best efforts to improve the image of the Padangsidimpuan IAIN by conducting socialization and self-introduction to the community and maintaining the good reputation they have had so far.

From the results of the $t$ test, SPSS output is obtained as follows:

Table 2. t-test Results

Group Statistics

\begin{tabular}{|r|r|r|r|r|}
\hline \multicolumn{1}{|c|}{ Jenis_Sklh } & \multicolumn{1}{|c|}{$\mathrm{N}$} & \multicolumn{1}{c|}{ Mean } & \multicolumn{1}{c|}{$\begin{array}{c}\text { Std. } \\
\text { Deviation }\end{array}$} & \multicolumn{1}{c|}{$\begin{array}{c}\text { Std. Error } \\
\text { Mean }\end{array}$} \\
\hline Citra $\begin{array}{r}\text { MADRASAH } \\
\text { SEKOLAH } \\
\text { UMUM }\end{array}$ & 160 & 3.4088 & .68440 & .08836 \\
\hline
\end{tabular}

From the table above it is known that the image of IAIN Padangsidimpuan from the point of view of Islamic school students is better than that of state school students. This is indicated by the average value (mean) of Islamic schools students 3.4088 while state school students only 3.1125. The difference in the image of IAIN Padangsidimpuan among respondents Islamic 
schools students and state school students is the difference (mean difference) of 0.2963 .

Furthermore, from the SPSS output, the significance value (sig.) Is 0,000. Because this value is smaller than $\alpha=0.05$, it means that it rejects H0. In conclusion, there are differences in the image of IAIN Padangsidimpuan among Islamic school students and state school students, where the image of IAIN Padangsidimpuan from the point of view of Islamic school students is better than state school students. In this case, improvements need to be made so that public school students can have a better image of the IAIN Padangsidimpuan.

Furthermore, from the SPSS output, the significance value (sig.) Is 0,000. Because this value is smaller than $\alpha=0.05$, it means that it rejects $\mathrm{H} 0$. In conclusion, there are differences in the image of IAIN Padangsidimpuan among madrasa students and public school students, where the image of IAIN Padangsidimpuan from the point of view of madrasa students is better than public school students. In this case, improvements need to be made so that public school students can have a better image of the IAIN Padangsidimpuan.

Furthermore, the results of data processing with ANOVA test obtained SPSS output as follows:

Table 4.6. ANOVA Test Results

\section{Descriptives}

Citra

\begin{tabular}{|c|c|c|c|c|c|c|c|c|}
\hline & \multirow{2}{*}{$\mathrm{N}$} & \multirow{2}{*}{ Mean } & \multirow{2}{*}{$\begin{array}{c}\text { Std. } \\
\text { Deviation }\end{array}$} & \multirow{2}{*}{$\begin{array}{l}\text { Std. } \\
\text { Error }\end{array}$} & \multicolumn{2}{|c|}{$\begin{array}{l}\text { 95\% Confidence } \\
\text { Interval for Mean }\end{array}$} & \multirow{2}{*}{$\begin{array}{c}\text { Minim } \\
\text { um }\end{array}$} & \multirow{2}{*}{$\begin{array}{c}\text { Maximu } \\
\mathrm{m}\end{array}$} \\
\hline & & & & & $\begin{array}{l}\text { Lower } \\
\text { Bound }\end{array}$ & $\begin{array}{l}\text { Upper } \\
\text { Bound }\end{array}$ & & \\
\hline $\begin{array}{l}\text { KURANG } \\
\text { MAMPU }\end{array}$ & 28 & 3.1534 & .66519 & .12571 & 2.8954 & 3.4113 & 2.06 & 4.59 \\
\hline $\begin{array}{l}\text { MENENG } \\
\mathrm{AH}\end{array}$ & 143 & 3.2369 & .49031 & .04100 & 3.1559 & 3.3180 & 2.24 & 4.65 \\
\hline MAMPU & 49 & 3.0888 & .57373 & .08196 & 2.9240 & 3.2536 & 2.06 & 4.41 \\
\hline Total & 220 & 3.1933 & .53523 & .03609 & 3.1222 & 3.2644 & 2.06 & 4.65 \\
\hline
\end{tabular}


Citra

\begin{tabular}{|l|r|r|r|r|r|}
\hline & \multicolumn{1}{|c|}{$\begin{array}{l}\text { Sum of } \\
\text { Squares }\end{array}$} & df & Mean Square & F & \multicolumn{1}{|c|}{ Sig. } \\
\hline Between Groups & .852 & 2 & .426 & 1.493 & .227 \\
Within Groups & 61.885 & 217 & .285 & & \\
Total & 62.737 & 219 & & & \\
\hline
\end{tabular}

From the table above it is known that there is actually no difference in the IAIN Padangsidimpuan image between groups of respondents from different family classes, because the significance value (sig.) Of 0.227 is much greater than $\alpha=0.05$. This indicates that IAIN Padangsidimpuan does not need to differentiate promotion methods for students from economically well-off families, middle class, or poor families. This means that the community, prospective new students, tend to have the same perception about the image of the Padangsidimpuan IAIN so far. The IAIN Padangsidimpuan does not need to design special promotions, to enhance its image, to students who come from economically well-off families, the middle class or the poor.

Therefore, the organizer of IAIN Padangsidimpuan only needs to design and differentiate promotion techniques to Islamic school institutions and state schools and not based on the economic backgrounds of students' families.

\section{DISCUSSION}

Although the image of IAIN Padangsidimpuan among high achieving students in the City of Padangsidimpuan is included in the good category, it does not mean that IAIN Padangsidimpuan does not need to make improvements. The image of the IAIN Padangsidimpuan can still be improved to obtain better grades. This means that the manager of the Padangsidimpuan IAIN must still make the best efforts to improve the image of the Padangsidimpuan IAIN by conducting socialization and self-introduction to the community and maintaining the good reputation they have had so far. Many things can be done to improve the image of the IAIN Padangsidimpuan in the eyes of the community. The manager of this institution should cooperate with well-known institutions at the 
national and international levels. These forms of cooperation and their implementation are exposed to the public through the role of the media such as newspapers, radio and television. This will be even better if IAIN Padangsidimpuan is able to present important figures in several important events at IAIN Padangsidimpuan. Some of these things have actually been started by the management of IAIN Padangsidimpuan, but the intensity and reporting to the wider community is still lacking compared to some universities in Sumatra.

Furthermore, from this study it was found that there were differences in the image of IAIN Padangsidimpuan among Islamic school students and public school students, where from the point of view of Islamic school students, the image of IAIN Padangsidimpuan was better than state school students. In this case, remedial action needs to be taken so that public school students can have a better image of the IAIN Padangsidimpuan.

Promotion and dissemination of IAIN Padangsidimpuan to general schools need to be optimized properly. Many things can be done in this promotion so that the results are better. To convince public school students about the quality of the IAIN Padangsidimpuan, the promotion team that should be sent to the field should be those who have good communication skills by bringing concrete evidence. For example, in the promotion team, alumni who are successful in the working world are included. They will provide testimonials and experiences during college and their relevance to the working world. Surely this is an interesting thing for prospective new students. In addition, the promotion is not only lecturing, but also by screening short films about the IAIN Padangsidimpuan in front of students and teachers. Of course what is conveyed in the promotion is a fact, not merely fiction. If what was stated during the promotion was not in accordance with reality, it would backfire for the IAIN Padangsidimpuan in the future. What is promised to prospective new students in promotional activities should be fulfilled and proven by IAIN Padangsidimpuan.

To attract and invite prospective new students to immediately decide to study at IAIN Padangsidimpuan, it is necessary to do a sales promotion. The methods include giving a discount on tuition fees and other facilities for the first 
few registrants. Another technique is to give souvenirs or gifts to the first few registrants. Of course, this must be adjusted to the available budget and applicable regulations.

Although the image of IAIN Padangsidimpuan among high achieving students from Islamic schools is better than state schools, that does not mean promotion to this institution can be ignored. Promotion and socialization of IAIN Padangsidimpuan to Islamic schools must still be carried out because it is worth remembering that other tertiary institutions, including general tertiary institutions, also do the same thing with IAIN Padangsidimpuan. They also intensely carry out socialization and promotion.

However, if it is seen based on family economic background, no significant difference was found in terms of the IAIN Padangsidimpuan image between different family economic backgrounds.

\section{CONCLUSION}

Based on this study it can be concluded that the image of IAIN Padangsidimpuan among outstanding students in Padangsidimpuan City is included in both categories. Furthermore it was found that there were differences in the image of IAIN Padangsidimpuan among Islamic school students and public school students, where Islamic school students looked at the IAIN Padangsidimpuan image better than public school students. This study also did not find any differences in the image of IAIN Padangsidimpuan between groups of respondents from the economic groups of well-off families, middle class, and poor. 


\section{REFERENCES}

Andriasan Sudarso, dkk., Manajemen Pemasaran: Teori dan Aplikasi dalam Bisnis, Yogyakarta: Andi, 2015.

Buchari Alma, Manajemen Pemasaran E Pemasaran Jasa, Bandung: Alfabeta, 2018

Darmadi Durianto, dkk., Strategi Menaklukkan Pasar Melalui Riset Ekuitas dan Perilaku Merek, Jakarta: PT. Gramedia Pustaka Utama, 2004.

Enung K Rukiati dan Fenti Hikmawati, Sejarah Pendidikan Islam di Indonesia,Bandung: Pustaka Setia, 2006.

Getut Pramesti, Kupas Tuntas Data Penelitian dengan SPSS 22, Jakarta: PT. Elex Media Komputindo, 2014.

Husein Umar, Desain Penelitian MSDM dan Perilaku Karyawan, Jakarta: PT. Rajagrafindo Persada, 2008.

Istijanto, Aplikasi Praktis Riset Pemasaran:Cara Praktis Meneliti Konsumen dan Pesaing, Jakarta: PT. Gramedia Pustaka Utama, 2009.

Muhammad Adam, Manajemen Pemasaran Jasa, Bandung: Alfabeta, 2015.

Rekalpitulasi SPMB IAIN Padangsidimpuan Tahun 2018

Riduwan, Belajar Mudah Penelitian:Untuk Guru-Karyawan dan Peneliti

Pemula, Bandung: Alfabeta, 2010.

Rini Dwiastuti, dkk., Ilmu Perilaku Konsumen, Malang: UB Press, 2012.

Sambas Ali Muhidin dan Maman Abdurrahman, Analisis Korelasi, Regresi danJalur dalam Penelitian, Bandung:Pustaka Setia, 2009.

V. Wiratna Sujarweni, Metodologi Penelitian Bisnis \&Ekonomi, Yogyakarta: Pustaka Baru Press, 2015.

Vinna Sri Yuniarti, Perilaku Konsumen: Teori dan Praktik , Bandung:Pustaka Setia, 2015. 
334 | TAZKIR: Jurnal Penelitian Ilmu-ilmu Sosial dan Keislaman

Vol. 05 No. 2 Desember 2019 